\title{
COMMUNITY HEALTH CENTER RESILIENCE IN DISASTER MANAGEMENT: A NARRATIVE REVIEW
}

\author{
Ani Sutriningsih',2), Chatarina Umbul Wahyuni'3), Setya Haksama4) \\ 1) Faculty of Health Sciences, Universitas Tribhuwana Tunggadewi Malang \\ 2) Doctoral Program, Faculty of Public Health, Universitas Airlangga, Surabaya \\ 3) Department of Epidemiology, Faculty of Public Health, Universitas Airlangga, Surabaya \\ 4) Department of Health Administration and Policy, Faculty of Public Health, \\ Universitas Airlangga, Surabaya
}

\begin{abstract}
Background: Indonesia's disaster management context uses a system called Pentahelix, which is defined as a more optimal framework for activities and jobs. The community health center is the front line that plays a significant role in the preparedness and management of disaster victims. The aim of this study is to review the resilience of disaster management in community health center.

Subjects and Methods: This was a narrative review. Sources of data in this study come from articles obtained through PubMed, Science Direct, and Scopus databases. The keywords used were "disaster" OR "emergency" AND "resilience" AND "hospital" OR "healthcare" OR "health care". The inclusion criteria consisted of: (1) articles published in English; (2) research or review articles; (3) publication from 2014-2019.

Results: Based on the available articles, it was found that the resilience of public health centers was generally identified in 5 aspects, namely physical toughness, social resilience, institutional toughness, infrastructure resilience, and vulnerability.

Conclusion: Community health center resilience is needed to ensure that community health center will be resilient, safe and will continue to operate in the event of an emergency or disaster.
\end{abstract}

Keywords: resilience, community health center, disaster

\section{Correspondence:}

Ani Sutriningsih. Faculty of Health Sciences, Universitas Tribhuwana Tunggadewi Malang/ Doctoral Program, Faculty of Public Health, Universitas Airlangga, Surabaya. Email: ani.sutriningsih-2018@unair.ac.id

The $7^{\text {th }}$ International Conference on Public Health Solo, Indonesia, November 18-19, 2020 327 https://doi.org/10.26911/the7thicph.04.12 